\title{
Management of Priapism
}

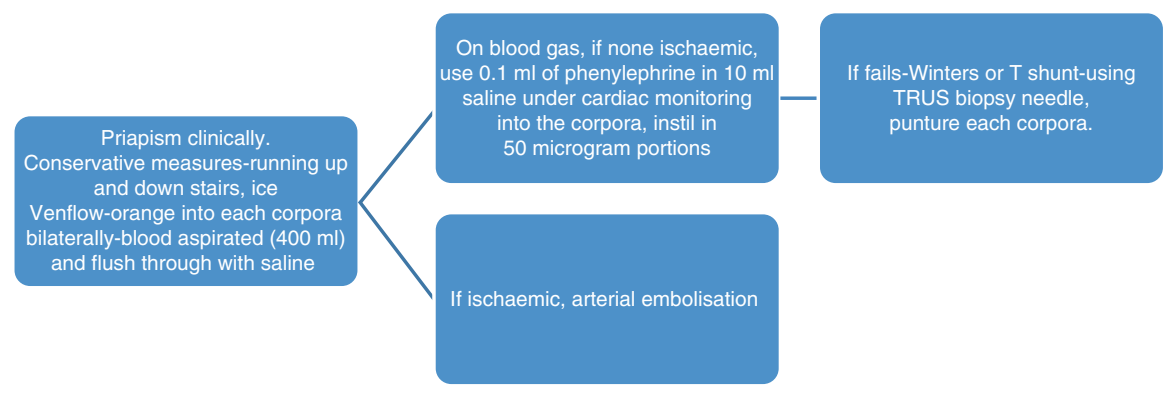

\section{Suggested Reading}

Ajape AA, Bello A. Penile gangrene: an unusual complication of priapism in a patient with bladder carcinoma. J Surg Tech Case Rep. 2010;3:37-9.

Babcock C. Emergency department management of priapism. Emerg Med Pract. 2017;19(1):1-16. Montague DK, Jarow J, Broderick GA, Dmochowski RR, Heaton JP, Lue TF, Nehra A, Sharlip ID. American Urological Association guideline on the management of priapism. J Urol. 2003;170(4 Pt 1):1318-24. 